\title{
BATANG STEAM POWER PLANT, THE STRUGGLE OF INTERESTS BETWEEN THE CENTRAL GOVERNMENT AND THE LOCAL COMMUNITY
}

\author{
Ery Agus Priyono \\ eap_fh_undip@yahoo.com
}

\begin{abstract}
The electricity power crisis will hit the island of Java 2018 due to growth in electrical load continues to increase with growth per year to reach about nine percent. Steam Power Plant in Batang District has become the main hope in overcoming the electricity power crisis, especially in Java and Bali.Construction of the power plant in the district of Batang situated on land and at sea. There is no problem with land area because it has in accordance with the Spatial Batang District regulation, but the position at sea It crash to Government Law (PP) no. 26 year 2008 of National Spatial Plan. It triggers a conflict between central and local governments on the one hand with the local community on the other hand. Resolution of the conflict can not be patterned positivistic application of the law but the application of laws that are pluralism that enables a win-win solution.
\end{abstract}

Keywords : electricity crisis, steam power plant, environment, local community, positivistic law and legal pluralism.

\section{Introduction}

The electricity power crisis will hit the island of Java. Along with economic growth, growth in electricity consumption is also growing rapidly. Based on the results of PLN studies, Java is inferred to experience an electricity 
crisis in 2018 due to growth in electrical load continues to increase with growth per year to reach about nine percent ${ }^{1}$. To anticipate the crisis required additional 5000 or 4000 MW every year, especially Java and Bali because of the high economic growth in both islands. ${ }^{2}$

Steam Power Plant in Batang has become the main hope in overcoming the electricity power crisis, especially in Java and Bali. Batang Power Plant is targeted to be the largest power plant in Indonesia due to generate 2000 megawatts from two power plants. The construction of the power plant is estimated to require a total cost of $\mathrm{Rp} 35$ trillion, it began construction on October 6, 2013. ${ }^{3}$

Construction of the power plant in the district of Batang situated on land and at sea. The position on the ground, namely in the village Karanggeneng, Kandeman Sub- District, Batang District, and it was in accordance with the Spatial Batang District (Article 49 Batang District Regulation No. 07 Year 2011 on Spatial Planning of Batang, Year 2011-2031). ${ }^{4}$ Position at sea for building construction for getting sea water and heat water disposal, as well as the jetty and coal conveyor, located at sea area Ujungnegoro-Roban. ${ }^{5}$

If the development planning of Batang Steam Power Plant remains in the Karanggeneng village and build infrastructure on the seaside of Ujungnegoro-Roban which has been designated as Protected Areas National Natural Park of the Sea (Annex VIII sequence number 313 PP No. 26 Year 2008 on RTRWN and Article 46 paragraph (2) d Central Java Provincial Regulation

\footnotetext{
${ }^{1}$ http://www.esdm.go.id/berita/39-listrik/6745-tanpa-pertumbuhan-pembangkit-2018-pulaujawa-krisis- listrik.html

${ }^{2}$ lbid.

${ }^{3}$ lbid.

${ }^{4}$ Biro Lingkungan Hidup Provinsi Jawa Tengah dalam Suara Merdeka 12 Maret 2012

${ }^{5}$ lbid.
} 
No. 6 of 2010 on spatial Central Java province Years 2009-2029), then the location of the Batang's electricity power plant is not in accordance with the spatial plan regulation, so that the EIA document can not be assessed and must be returned to the proponent. This is consistent with the mandate in Article 4 paragraph (3) of Government Regulation No. 27 Year 2012 on Environmental Permit.

\section{Reseach Method}

a. Why the Case of Batang Steam Power Plant has not been over yet?

b. How should solutions be reached to achieved together happiness?

\section{Discussion}

a. Why the Case of Batang Steam Power Plant has not been over yet?

Positivistic Law Approach

Law was reduced from social facts that accompanied its formation, so that a skeleton without content, dry, away from the values of humanity and justice. ${ }^{6}$ Law understood by officials simply as a set of written rules that must be done by government officials and must be obeyed by the people.

The following quote is an affirmation of the statement above, President Director of PT. PLN Sofyan Basir asserts land acquisition for power plant refers to the law no. 2 of 2012 on Land Acquisition for Development For Public interest must be resolved.

\footnotetext{
${ }^{6}$ Suteki. Kebijakan tidak menegakkan Hukum (non enforcement of Law) demi Pemulian Keadilan Substantif. Pidato Pengukuhan Guru Beasar.Semarang BP UNDIP. 2010. HIm. 17 
He added that the Batang's power plant project which was delayed are believed will bring a positive impact to the surrounding community so that no term will be detrimental for local residents. Therefore, he asked the public to better understand and support the Jokowi Government program, in order to increase electricity production in Indonesia.

Development in all fields is a definiteness that needs to be pursued in order to increase prosperity for all people. Development that relies only on one aspect, namely the economy without paying attention to the human aspect and moreover environment will only create a suffering now and future that will continue to be remembered. The construction carried out in the name of prosperity that just creates losses are not small, especially on the environmental aspects. ${ }^{7}$ Hardin in his work "The Tragedy of the Common" which quoted by Rahmadi confirms economic reasons are often moving human behavior or decisions taken by human beings individually or in groups, especially in relation to the common property, which inflicts which is detrimental for everyone, that is a tragedy for all. ${ }^{8}$

Legal Theory Development as propounded by Mochtar Kusumaatmadja $^{9}$ that laws are made to be appropriate and should pay attention to community legal awareness. Laws should not hamper modernization. Law to serve as a means of a renewal of society can and should be based on the legalization of state power. This is related to the maxim, " law without authority/power is an imagination and authority/power without law is tyranny". There is a legal certainty if the law

\footnotetext{
${ }^{7}$ Sulaiman. N Sembiring (Penyunting). Hukum dan Advokasi Lingkungan. Jakarta. ICEL. 1998.hlm. 25

${ }^{8}$ Takdir Rahmadi. Hukum Lingkungan di Indonesia. Jakarta. RajaGrafindo Persada. 2011. HIm. 9

${ }^{9}$ Mochtar Kusumaatmadja dalam Abdul Manan. Aspek-Aspek Pengubah Hukum. Jakarta. Kencana Prenada Media Grup. 2006. Hlm. 21
} 
was made in writing in accordance with applicable regulations and are set by the state.

Economic growth must be balanced with attention to the quality of life also includes the maintenance of a healthy and beautiful environment, and your relaxation, which relaxes the tension and restore the spirit for doing creation. Work not only to pursue of productivity and only justified economically, it must be meaningful to the workers as service and assistance to their neighbors, as well as revealing the identity through the work of copyright. Technology should not be left the instinct to realize anything that might be made; but have to obey values consideration should lead him to determine to chose, which strictly necessary. ${ }^{10}$

One more dimension that needs to be added is the religious dimension. ${ }^{11}$ Transcendent paths that allow a dialogue between man and God be opened. Humility to acknowledge the limitation of human reason should be developed. Dominium terrae should be accepted as an obligation to preserve and utilize its abundance of nature is responsible for accountable to the Creator, it is also a responsibility to future generations. Elements of ethics should be included when the scientific reasoning included when forming the law. Laws should provide benefit to man, not man for the law. Law in Indonesia should be served happiness to the people of Indonesia. ${ }^{12}$

The settlement in the case of Batang steam power plant has not been finished because the government (both central and local) as a government administrator was authorized to regulate its citizens in the name of the law,

\footnotetext{
${ }^{10}$ Liek Wilardjo. Realita dan Desiderata. Yogyakarta. Duta wacana University Press. 1990. 158

${ }^{11} \mathrm{lbid}$.

${ }^{12}$ Satjipto Rahardjo. Membedah Hukum Progresif. Jakarta. Penerbit Buku Kompas. 2008. HIm. 9
} 
without giving sufficient attention to the conditions that occur in the community. The government felt entitled to the argument "based on the law to enforce the law", a steam power plant based on government decree was determined in Batang District, so have to be done in Batang. Justice for the people at the site of the power plant project is not substantive in law enforcement. The law not more than as a bulk of regulation which has to be done. $^{13}$

It is very ironic that the country which is mandated by the Preamble of the 1945 Constitution to create prosperity for all Indonesian people is precisely the cause misery for its citizens. The unacceptable argument for the public interest the society had to sacrifice their happiness. In Consideration of establishment of Law No. 2 of 2012 on Land Procurement for Development for General interest numbers 1 and 2 stated that in order to realize a society that is just, prosperous based on Pancasila and the Constitution of the Republic of Indonesia Year 1945, the government needs to implement development; that in order to ensure the implementation of development for public interest, the necessary land procurement carried out by promoting humanitarian principles, democratic and fair.

1. When Dominancy less Consultation and Compromise (EIA a Controversial study)

Batang power plant construction initiated two years ago is still reaping the pros and cons. Pros argue that the project needed to meet energy needs, employment/business, and spur economic growth. Cons parties insisted on the presence of energy plants that pollute the air

\footnotetext{
${ }^{13}$ Theo Huibjers. Filsafat Hukum dalam Lintasan sejarah. Yogyakarta . Penerbit Kanisius. 1982. HIm. 157
} 
because fly ash, damage the soil cause of bottom ash, damaging coastal and marine ecosystems for the distribution of heat, and there are a number of farmers have lost their livelihoods due to land acquisition ${ }^{14}$

Both sides are in fact expect the results of studies of environmental impact assessment (EIA) to provide answers to their dreams and anxieties. But after EIA document legalized, there are still many members of the public and environmentalists protested and rejected the presence of the project. Is there anything wrong on the EIA of the project?

The EIA is a study of the impact of the planned activity on the environment. The environment mentioned include physical chemicals aspects such as the condition of water, soil, air, land, biological aspects, including flora and fauna; as well as the socioeconomic and cultural aspects of them a livelihood, income level, the pattern of social relations, health, and public perception. ${ }^{15}$

The results of environmental impact analysis study include three documents, namely terms of reference, (the scope of the study) the environmental impact assessment (reliably) or impact statement, and environmental management plan / environmental monitoring plan ( RKL / RPL). As a feasibility study, environmental impact analysis is in the downstream position because it was held after the economic and technological feasibility studies.

Unfavorable as well, EIA is done after the specified location and project specifications declared eligible. Theoretically, EIA could declare the project EIA is not feasible due to greater negative impact

\footnotetext{
${ }^{14}$ Sudharto P Hadi. Amdal PLTU Batang. 2014. HIm.1

${ }^{15}$ Takdir Rahmadi. Op. Cit. HIm. 91 
than positive impact, and there is no technology that can manage such impacts. But very rarely, can even be counted on the fingers, EIA studies reject or declare a project is not feasible. Most of the environmental impact analysis study states that project is eligible with management. This means that the impact is predicted to be managed with a technological approach, institutional, or social. ${ }^{16}$

In the case of EIA of Batang steam Power Plant, experts who review the EIA document stating project was feasible if the proponent perform as stated in the document management environmental management plan (RKL / RPL.) As if to these demands commitment from the proponent, the statement added the phrase "if the proponent wants to manage" (SM, 09/07/13). Apparently, the results of the EIA study only give satisfaction to the pro, while the cons are still questioning the land acquisition and compensation. ${ }^{17}$

Ideally, when the EIA was approved, there was no protest and social flare up because this aspect be part of the social components observed since the preparation of terms of reference, in the preparation of EIA social field there are two paradigms that determine how the process of environmental impact analysis carried out, namely the paradigm of technical and community development (CD) or community development. ${ }^{18}$

Technical paradigm emphasizes the scientific method as an objective way to present information to decision makers. On the other hand, community development paradigm argues public demand rather

\footnotetext{
${ }^{16}$ Takdir Rahmadi. ibid. 95

${ }^{17}$ Sudartho P Hadi. Op.cit.

${ }^{18}$ Sudarto P. Hadi ibid.
} 
than on rational decision making but on transparent decision making. That is, the technical approach emphasizes the results, while the CD approach to the process.

In the context of the Batang steam power plant project, which since its inception has happened conflict, means business, as usual, should be abandoned and a community development approach to be an option. Initiator and composer EIA studies not only announced the project to the public and held a public consultation on a reference framework but also at the time of the draft reliably and environmental management plan is completely composed. The technical approach to the scientific method is said to be an objective by the pro shows the government (central and local) only pay attention to the legal aspects of formalistic, as part of the paradigm of power leaving the moral paradigm. ${ }^{19}$

When the EIA approved, the public had the right to obtain the documents to monitor whether the management order to tackle the negative impacts have been implemented. Still, the party demanding compensation and the fear of losing their livelihoods should have been included at this stage of EIA studies. Likewise, ideas and requests raised in the discussion between the Governor Ganjar Pranowo and various parties last September 2016.

It should be recognized decision on a project will not be able to satisfy all parties, but Batang steam power plant project should not be negated people potentially to be adversely affected. Learning from

\footnotetext{
${ }^{19}$ Esmi Warassih. Pranata Hukum Sebuah Telaah sosiologi. Semarang. PT. Suryandaru Utama. HIm.52
} 
Kedungombo and other large projects in the country, the suffering of the citizens would not be offset by the positive impact that enjoyed by parties and other groups. Had the incident repeated, that is mean principles of justice was already ignored. Borrowing a term Jeremy Bentham "the greatest happiness for the greatest number" then it should be understood that the law is used as the basis to act for the authorities (central and local) should have sought as much as possible, not only uphold "state Law" but also "living law" under the umbrella " natural law "(ethical, moral, and religious) so that development jargon to improve the well-being can really be implemented in reality. ${ }^{20}$

b. How should solutions be reached to serve together happiness?

In The domain of non-doctrinaire, the law is not merely understood as "positive law" which is characterized as a Power product which controls everyone (das sollen) accompanied with clear sanctions, although it is sometimes not clear. the law is not sui generis that can not be mixed with un law, but the law is understood as a sub-system within a system of social relations. It is clear that in the conditions of the law as an independent variable (where the community becomes the dependent variable) but on the condition that another law as the dependent variable (where the community becomes independent variable) depending on which is more dominant in the tug of war between the two.

Socio-legal studies are not really new. Interdisciplinary studies is a 'hybrid' of a large study of the science of law and the science of law from a

\footnotetext{
${ }^{20}$ Werner Menski, Comparaive Law in A Global context (the Legal system of Asia and Africa) Second Edition. Cambridge University Press. 2006. HIm. 187
} 
societal perspective born before. ${ }^{21}$ The need to clarify the legal issues in a more meaningful theoretically fertilize the study. Meanwhile, practical, this study is also needed to explain the working of the law in the everyday life of the community. ${ }^{22}$

In certain contexts both in the realm of theoretical as well as practical, mainstream legal studies can not answer the questions of justice concerning the marginalized. Many social problems are very complicated and can not be answered textually and mono discipline, and in this situation, the more fundamental explanation and enlightening can be obtained in an interdisciplinary manner. Therefore, it takes a legal approach that could explain the relationship between law and society. Law has many faces, and therefore among scientists (law), there is no single agreement of understanding. In general, the law is defined as a set of rules of conduct regulating and forcing people, also regulates the settlement of disputes. ${ }^{23}$

Mudjahirin Thohir explained based on social relationship theory, that the human relationship is equal to transactions in economics. People give and take while, on the one hand, seeks to maximal results obtained and the other to reduce or avoid losses, pain, expense and humiliation ${ }^{24}$

Understanding the structure of society in conflict areas (the pros and cons power plant) is in a state of peace, according to the theory of

\footnotetext{
${ }^{21}$ Sulistyowati Irianto,dkk Kajian Sosio-Legal. Editor , Andriaan W Bedner dkk. Denpasar .Pustaka Larasan. 2012. HIm. 16-18, lihat Sulistyowati Irianto dan Sidharta. Metode Penelitian Hukum Konstelasi dan refleksi. Jakarta. Pustaka Obor Indonesia. 2013 hlm. 173

22 The definition of the law is not multifacted because it depends on the perspective of people on law itself. See John Henry Merryman. The Civil Law Tradition.

California. Stanford University Publisher. 1990. HIm. 65

${ }^{23}$ Roger Cotterrell. Law, Culture, And Society. Legal Ideas in the Mirrorof Social Theory. Hampshire. 2006. HIm. 18

${ }^{24}$ Mudhjahirin Thohir. Teori -Teori social . Bahan Kuliah PDIH, tahun 2014
} 
exchange is an interdependent bond between community members themselves, who exchanged interests in order to meet their needs. Exchange Theory/exchange (Exchange Theory of Peter Michel Blau), Blau said "in social association can be conceptualized as an exchange of activity, tangible or intangible and more or less rewarding or costly between alt least two people not only in market relations but Also in friendship even in law ${ }^{25}$

In view of the functional structural theorists, people who are on the territory understood as a society should be considered as a system composed of the parts are interrelated and each influences the other on a reciprocal basis. Although social integration will never be achieved completely fast, in principle, the social system always tends to move towards a dynamic equilibrium. Disfunctionalization, tensions, and distortions always happen, but in the long run, this situation will be resolved through gradually adjustment and institutionalization process.

In order to solve Problems of Batang steam power plant, cultural and religious approach is required, by forming a communication forum. The goal, giving space issues, in social, economic and citizen issues that are not logical, in order to hold a discussion around the table, Said the Governor of Central Java, Ganjar Pranowo, further, Ganjar asked some environmental experts from five major universities in Indonesia, to participate and be accountable for results of the study recommendations Analysis Issues Environmental Impact assessment (EIA) of Batang steam power plant construction. A fifth of the college is, Diponegoro University, Gadjah Mada University, Soegijapranata.Catholic University and the University of Sultan Agung.

\footnotetext{
${ }^{25}$ Peter Michel Blau. Exchange and Power in Social Life. Transaction Publisher . 1964. hlm 88
} 
According to the approach of conflict, the basic assumptions for the understanding legal problems is that every society is always experiencing social changes, social conflicts, impositions by a number of members of the public against members of the community. Public regulatory bodies, namely the state, is not a neutral apparatus, but directly involved in the conflict. The cause of the conflict is the lack of social commensurate. In this case, the law is often used for the benefits of the ruling class.

A great progress is happening in the world of law, namely with the introduction of a theory, namely Pluralist Legal Theory, by Werner Menski, law professor from the University of London, England, in his book "Comparative Law in a Global Context" formulate Theory Relevant laws to address the legal issues that arise in the era of globalization. Menski rejects the concept of "anti-pluralist" or the concept of "Unification visions" or "visions of Globalised uniformization, made by America led initiatives", which basically seeks to unify the international vision globalized world under the vision of the American way, the crucial issues concerning law, justice, and Human Rights.

Facing the era of globalization, an expert in modern law have left three approaches classical laws that tend to extremes of narrow only use one type of approach, whether normative (positivistic), empirical (sociological, anthropological, psychological and other) or a value approach and the moral (philosophical), triangular theory concept of legal pluralism (the concept of the triangle facing legal pluralism in the era of globalization) using all three approaches. 
Law as a global phenomenon has in common throughout the world, in the sense that everywhere the law consists of the basic ethical values, social norms, and rules made by the state, though of course, in reality, there are many variations of culture more specific. It is only confirmed on the basic premise that has been known, that all laws are specific culture and that in various areas of law such as contracts. Marriage and killing is a universal phenomenon, which seemed constantly changing from time to time

By using the approach of the three main types of law that is the law created by society, the law created by the state and law emergence through the values and ethics, then conflicts then the law will still be able to maintain legal certainty (legal positivistic), Sensormatic by adopting laws/habits of society, including in resolving conflicts between them (living law) and the law constituted with religious moral ethics. Based on this pluralist approach the law can be implemented flexibly and should not use the legal system (courts) to finish it, even it is possible to resolve disputes that arise in the community with a non-legal approach (non-enforcement of law)

\section{Conclusion}

a. Causes of conflict between communities in the area that will be built at the steam power plant not go over because of implementation positivistic approach to law. This approach reduces the laws of social facts that accompanied its formation, so that a skeleton without content, dry, away from the values of humanity and justice. Law understood by officials 
simply as written rules must be enacted by implementers and must be obeyed by the people.

b. The Government of the Reformation order is still using the paradigm of power in governing the country. In such a position, then the government is easy to be arrogant, overbearing, and arbitrarily, without regard to the interests of people who stand on the opposite side basically, have the same rights as other citizens as part of Indonesian citizens

c. The legal pluralist approach, it will be easier to use to solve a real problem that occurs in the community, because by using that approach the interests of the state, society is framed in the law based on the values of the fundamental beliefs and believed by many citizens.

\section{Acknowledgement}

It is the time the for the government took off power paradigm in any implementation of policy, for whatever reason. Power Paradigm as applied by the New Order government, have proven unsuccessful in serving Indonesian community reaching prosperity. The government better using the new paradigm (at least in contrast to paradigm power) that is based paradigm of moral law. The Paradigm demands to the government in implementing policy based not solely on the purpose of material development, but also to be able to realize the objectives of spiritual development, as a piece of poetry in Indonesia Raya songs ....... bangunlah jiwanya bangunlah badannya. Untuk kebahagian rakyat Indonesia. (develop the soul ..develop the physic ) for the happiness of the people of Indonesia. 


\section{References}

John Henry Merryman. The Civil Law Tradition. California. Stanford University Publisher. 1990

Liek Wilardjo. Realita dan Desiderata. Yogyakarta. Duta wacana University Press. 1990

Roger Cotterrell. Law, Culture, And Society. Legal Ideas in the Mirror of Social Theory. Hampshire. 2006

Esmi Warassih. Pranata Hukum Sebuah Telaah sosiologi. Semarang. PT. Suryandaru Utama

Peter Michel Blau. Exchange and Power in Social Life. Transaction Publisher . 1964

Ronny Hanitijo Soemitro. Studi Hukum dan Masyarakat . Bandung .Penerbit Alumni. 1985.

Satjipto Rahardjo. Membedah Hukum Progresif. Jakarta. Penerbit Buku Kompas. 2008

Sulistyowati Irianto,dkk Kajian Sosio-Legal. Editor, Andriaan W Bedner dkk. Denpasar .Pustaka Larasan. 2012.

Sulistyowati Irianto dan Sidharta. Metode Penelitian Hukum Konstelasi dan refleksi. Jakarta. Pustaka Obor Indonesia. 2013

Suteki. Kebijakan tidak menegakkan Hukum (non enforcement of Law) demi Pemulian Keadilan Substantif. Pidato Pengukuhan Guru Beasar.Semarang BP UNDIP. 2010.

Theo Huibjers. Filsafat Hukum dalam Lintasan sejarah. Yogyakarta . Penerbit Kanisius. 1982.

Werner Menski, Comparaive Law in A Global context (the Legal system of Asia and Africa) Second Edition. Cambridge University Press. 2006 
Batang Steam Power Plant, The Struggle Of Interests Between The Central Government And The Local Community

http://www.esdm.go.id/berita/39-listrik/6745-tanpa-pertumbuhan-pembangkit-

2018-pulau-jawa-krisis- listrik.html

Biro Lingkungan Hidup Provinsi Jawa Tengah dalam Suara Merdeka 12 Maret 2012 